\title{
The Application of Internet of Things in the University Library
}

\author{
Wei Nie \\ Feixian Campus, Linyi University, Linyi, Shandong, China \\ lydxfxnw@163.com
}

\begin{abstract}
Keywords: Internet of things; Radio frequency Identification technology; Electronic label; University library; Books management
\end{abstract}

\begin{abstract}
The rapid development of computer technology, communication technology, sensing technology and other new technologies, Internet of Things (The Internet of things) is becoming a reality. Radio frequency identification technology (Radio, Frequency Identification RFID) as a key technology to build the "Internet of things" has been more and more attention in recent years. RFID technology has great application potential in many industries, with the rapid development of RFID technology as the core, to promote its application in various fields, is a necessary way to build the omnipresent networking. The application of RFID networking key technology is the main concern of this thesis in the university library management system.

The university library plays a more important role in the information age. Although most libraries use the barcode and magnetic identification, computer network, computer software and other modern management mode and technology, but there are still many problems in library management and staff, Such as the use of books, but also the process of time and effort, the rapid inventory of books, search, random shelf books and so on, the problem is still not well resolved, hindering the improvement of library management and service level. Library resources use networking technology of RFID library management mode, optimize and integrate automation in library management, network and intelligent library management. The use of networking technology to achieve scientific and accurate management of books, including the sorting process, automatic tracking, borrow and return books as data collection. In order to provide personalized service, library and information service is quick and accurate for the readers, meet all levels of people's needs.

With the rapid development of computer technology, communication technology, sensor technology, network technology, the next generation of the Internet will be towards the direction of the development of the Internet of things. "Internet of things" from the literal meaning of understanding is "the Internet of things connected", that is to say the Internet of things is based on the extension and expansion of the internet, The foundation and the core of things is still the Internet, it is the extension and expansion of the client to any goods and goods, to exchange information and communication items between people. All kinds of objects in the real world can be connected to the Internet of things, so it is convenient to identify, manage and control.

The university library is the Resource Center for information sharing, is the academic activities and the knowledge of the exchange center, is an important part of teaching and scientific research. The Ministry of education has put the library books as the basic conditions, one of the subject is an important indicator of university evaluation. With the gradual expansion of the university scale, the scale and amount of books in libraries of colleges and universities are increasing, so how to manage the huge amount of books and a large library, so that readers can book needed to quickly and accurately find, let the library books to achieve fast shelves, racks and inventory, has become the most important issues facing the university library. The university library should be from academic research, user learning, communication needs, continue to expand the area of services and content, integrated into the user's learning research, providing knowledge services for users and applications whenever and wherever possible, the wireless radio frequency identification technology of the Internet of things, to solve the current problems need to be solved. The library management system and sensing device the RFID network, the use of books, book service and management will be more convenient and fast, the traditional library will be upgraded to the intelligent library.
\end{abstract}




\section{The Concept of Internet of Things}

The concept of networking is proposed in 1999, was based on the Internet, RFID (Radio-frequency Identification) technology, EPC (Engineer, Procure, Construct), on the basis of the Internet, the use of radio frequency identification technology, wireless communication technology, global positioning system, construct a contains all things in the world and real Internet "the Internet of things real-time information sharing" (IOT).

Things can be understood from the following aspects: first, the basis of the Internet of things and the core is still the Internet, Internet of things is based on the extension and expansion of the Internet based on a larger network; Second, networking client extend and expand to anything and material (Thing to Thing) between the communication and exchange of information. If the age of the Internet to achieve human (Human to Human) Internet exchanges, so the era of things can make people and things (Human to Thing) communication and dialogue, can also achieve things (Thing to Thing) connection and interaction. But here the "objects" need to meet the following conditions to be included in the "Internet of things": there must be CPU; to have a storage function; to have the operating system; to have specialized applications; to have a data transmitter; a receiving device with the corresponding information to a data transmission path; communication; the protocol should follow the Internet of things; there are only recognizable numbers in the world network; to have automatic recognition function.

At present, both at home and abroad on the Internet of things is not a standard definition of a generally accepted definition is: things through radio frequency identification (RFID) device, infrared sensing device, laser scanner, various information sensing equipment global positioning system, in accordance with the contract agreement, will anything connected with the Internet and communication and information exchange with each other, in order to realize intelligent identification, positioning, tracking, a huge network covering the world monitoring and management.

The Internet of things based on Internet, the Internet of things will be able to build anything connected together through the network, and can be implemented on the item recognition, positioning, tracking and monitoring, information exchange and communication between objects, and RFID technology, is to let the goods "speak" the key technology. The idea of "Internet of things", RFID tags are stored in the standardization of information, and information is the information interoperability, automatic acquisition through the wireless data communication network, in the realization of recognition and positioning articles central information system, and then by the computer network open exchange or sharing of information, do a "transparent" the management of goods. The network structure from the network perspective, the Internet of things is through Internet (Internet) to connect many RFID systems and distributed systems to identify items identity in the WAN. The front end system using RFID technology as a means of identification items, the background system is real-time sharing of global goods information system based on Internet set up.

\section{The Connotation of the Internet of Things Library}

The definition of networking library is the library special items also include the library itself connected to the Internet through networking technology, build an implementation of intelligent management network system more on library items. From the aspect of generalized networking library refers to things in the inside of the library as the basis, all articles related to libraries and into the networking library system, node to form interlibrary network, finally a whole network system.

The networking library requires a variety of technical support, RFID radio frequency identification technology which is one of the key technologies. The networking library needs on the basis of RFID, combined with database technology, mobile communication technology, network technology and other advanced technology to build a network library has a large number of items of electronic tag and reader network system. The RFID tag stores a lot of standard information, through the wireless communication network collecting them automatically to the information 
processing center, convenient and fast recognition of library materials, make all kinds of goods with each other, and through the open Internet to realize information exchange and sharing, thus realizing the items "transparent" management. The future library will be used RFID technology, combined with the technology of the robot and automatic sorting technology to build self-service intelligent library.

\section{Characteristics of the Internet of Things Library}

After the completion of the Library Networking is a complete activity center, is one such wisdom center can become full, open the comprehensive academic resources information service center, build efficient, humanized and personalized service. It has the following main features:

\section{Building Intelligence}

The networking library will be an intelligent building, can various machinery and equipment in the building of the library implements intelligent control and comprehensive management of air conditioning system. It can monitor the content of toxic and harmful substances in the air, can carry out ventilation and disinfection. Through the automatic monitoring and control system can the lighting, temperature, humidity intelligent regulation, control of background noise. The intelligent fire, security system can ensure the safety of personnel and buildings. At the same time, the intelligent system can make all kinds of machine library automatic operation, maintenance, inspection and maintenance; greatly optimize the human, material resources distribution.

\section{Service Intelligence}

In the intelligent library, can through the Internet to various independent transactions linked to each other through the sharing of resources and information exchange platform, to construct an intelligent transaction processing system function, service management and decision-making. Through this system, the library staff can use a more scientific, more efficient new the way of learning and training, accept all kinds of knowledge and skills, improve the comparative analysis, of all kinds of information, refining capacity, provides intelligent service range for the readers.

\section{Communication Intelligence}

The means of exchange through the advanced Internet communication equipment and a variety of information, build a IOT based intelligent communication system, personalized service, intelligent custom services, can carry out information service by using the existing Internet, also can achieve a wider range of information resources sharing technology through the Internet of things.

RFID technology has been applied in the domestic public library and university library, practice has proved that RFID technology can greatly improve the working efficiency and service level, strengthen the library automation management level, has the advantage of There is nothing comparable to this. RFID management system is mainly used for Library and book service, placed in the position of self-check machine library, readers can quickly find and borrow books; books sorting machine can handle many types of books, 24 hours uninterrupted provide book service, book sorting machine can be carried out immediately after treatment in the reader book classification. Provide the efficiency of library management; RFID system also provides an appointment to take the book, readers can on the Internet without reservation to the museum library, the museum has to inform the reservation book, can automatically send a notification to the reader to pick up the book.

Can foresee the future of university library will likely help the robot technology and automatic sorting technology, intelligent full self-service library combined with RFID technology. At the same time the RFID logo will likely expand to other application fields of library management, such as purchasing documents, sorting process, asset management and other application of. RFID 
technology in the University library has become the future trend of modernization, intelligent library development, will give the modern university library brought epoch-making change, I believe the future of RFID technology will shine in university libraries.

\section{References}

[1] G.L.Li: The application and research of RFID technology in foreign libraries[J], Modern intelligence, (2010). No.11, p.156

[2] X.Y.Chang: Key problems and Strategies of Library RFID technology promotion [J], library journal,(2011).No.7,p.68

[3] K.L.Shen and J.Du: The research and Enlightenment of foreign libraries RFID application literature [J], Journal of the National Library of China, (2011).No.3,p.61

[4] T.J.Liu : The design of university library management system based on RFID Technology[J], Journal of science of teachers, (2010). No.5,p.81

[5] Rubin,Jenny . Overview of Design, Benefits \& Security[J], EPC global,(2009).No.6,p.349

[6] H.B.Cao : The construction of personalized service system of University Library under the Internet of things[J], Information theory and practice, (2011).No.3,p.70

[7] H.Yinghui and L.Guanyu, "Deseriptive models for Internet of Things, "in Intelligent Control and Information Processing(ICICIP) , 2010 International Conference on , (2010).p.483

[8] Fabian B, Gunther O.Security challenges of the EPC global network . Communications of the ACM. (2009).No. 7,p.121

[9] Q.L.Cao: Summary of research on the Internet of things[J], Software Guide, (2010).No.5

[10] K.He: Key technology of Internet of things and its development and Application[J], RF world, (2010).No.1,p.32 